\title{
To what extent do natural disturbances contribute to Andean plant diversity? A theoretical outline from the wettest and driest parts of the tropical Andes
}

\author{
M. Richter \\ Institute of Geography, University of Erlangen-Nuremberg, Germany \\ Received: 15 March 2009 - Revised: 2 June 2009 - Accepted: 3 June 2009 - Published: 13 October 2009
}

\begin{abstract}
This paper deals with natural disturbances and their impact on vascular plant enrichment at two climatically contrasting Andean ranges, i.e. the perhumid Cordillera Real in southern Ecuador and the arid Cordillera de Atacama in northern Chile. In the first case, main triggers for an additional input of pioneer species during succession stages initiated by perturbations are landslides, mudflows, and, to a lesser extent, cohort mortality, floods, and wildlife damages. Droughts and wind are stressors, which reduce plant growth but hardly plant diversity, in contrast to enhanced UV radiation with its mutagen effect. Though stress effects are similar in the Atacama, disturbance regimes differ considerably in this dry mountain environment. Here, most perturbations are of small dimension such as nitrogen inputs by feces of Lamoids and burrow activities of tuco-tuco mice, both of them fostering nitrophilous plant communities. Flooding, gelifluction, and other denudation processes such as sheet wash occur too, however, do not charge species enrichment in the dry Andes. Although the perhumid study site represents one of the world's plant diversity "hotspots" and, by contrast, the arid one a comparatively "coldspot", pioneer species during successive stages after natural disturbances contribute in a similar percentage to the total plant inventories (appr. 10\% of the species numbers). Relatively seen, natural disturbances are most important for species enrichment in the Atacama (200-500 species per $10000 \mathrm{~km}^{2}$ ), while most other ecological factors delimit plant survival. Instead, plant life at the Ecuadorian study area benefits from many climatic and edaphic site conditions, and consequently, disturbances are considered only one of many driving forces for its hotspot status $\left(>5000\right.$ species per $10000 \mathrm{~km}^{2}$ ).
\end{abstract}

Correspondence to: $\mathrm{M}$. Richter (mrichter@geographie.uni-erlangen.de)

\section{Objective and study areas}

There is evidence for a latitudinal gradient of decreasing diversity with an increasing distance to the equator. Thus, the evergreen tropics and subtropics tend to be the most diverse ecozones on Earth. In addition, centres of biological diversity are mostly situated in geodiverse regions with a great variety of environmental conditions. This is especially true for mountain areas with steep climatic gradients (Mutke and Barthlott, 2008; Clinebell et al., 1995).

Rapoport's Rule provides useful insights into diversity patterns on a worldwide scale that result from globally effective ecological controls. The rule states that latitudinal ranges of animal or plant species increase towards the poles (e.g. Willig et al., 2003). This allows for an initial explanation for the geographical pattern that marks the two extremes of diversity: "a chemostate-like system tending to become monospecific, and a Noah's ark or museum situation with an infinite number of species each represented by just one specimen" (Margalef, 1994).

Vascular plant biodiversity has been inventoried on a global scale by Mutke and Barthlott (2005) and Barthlott et al. (2007). Based on this, five centres with more than 5000 species of vascular plants per $10000 \mathrm{~km}^{2}$ have been identified. One of these "megadiverse hotspots" encompasses the northern Andes and their forelands in Colombia and Ecuador. The tropical Andes as a whole contain about one sixth of all plant species in less than one percent of the world's land area (Mittermeier et al., 1997).

However, Rapoport's Rule only roughly explains the general latitudinal gradient. On many meridional pathways deserts dictate the tropical-subtropical transition and minimise the diversity trend seriously even though transitorily. With respect to the Andes, this applies to the section of the diagonal axis crossing the mountain range at around $25^{\circ} \mathrm{S}$.

Published by Copernicus Publications on behalf of the European Geosciences Union. 

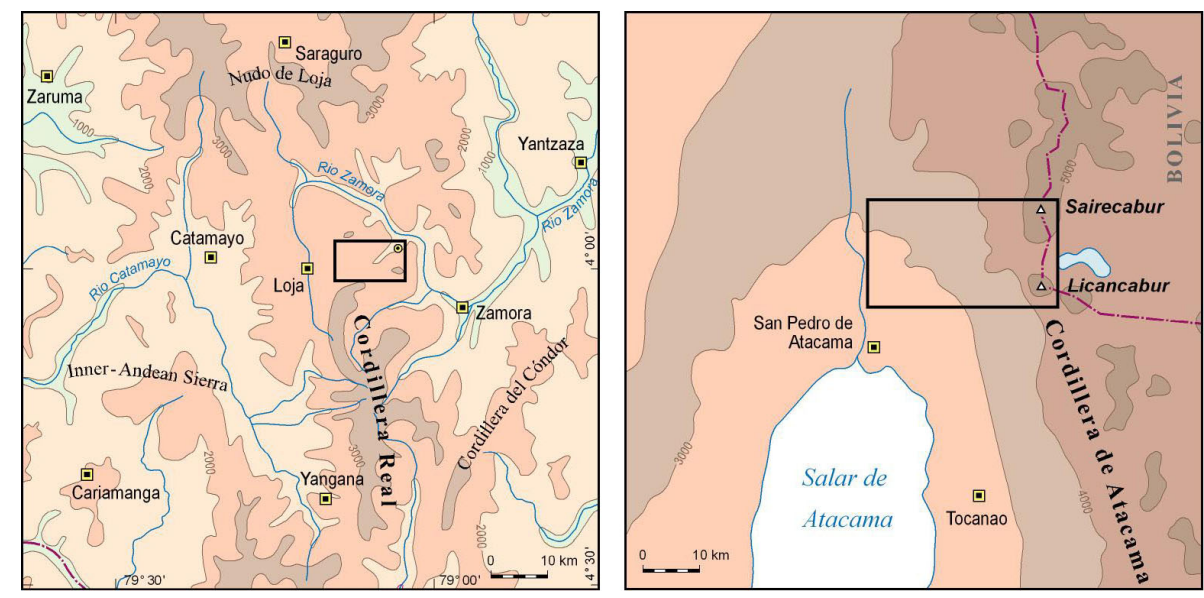

Fig. 1. Location of the study areas in southern Ecuador (left) and in northern Chile (right). Note the different extension of $250 \mathrm{~km}^{2}$ in the first and $725 \mathrm{~km}^{2}$ in the second case. While the smaller area of the Rio San Francisco Valley contains ca. 2000 native vascular plant species the more extended one west of the volcanoes Sairecabur and Licancabur hosts only ca. 250.

Thus, the section of the central Atacama Desert forms a counterpoint to the humid northern Andes. Especially the altitudinal belt between 1000 and $2200 \mathrm{~m}$ a.s.l. is mostly plantfree. Only the Coastal Cordillera harbours up to 200 vascular plant species per $10000 \mathrm{~km}^{2}$ and the altitudinal belts from 2200 to $5000 \mathrm{~m}$ a.s.l. fall into the next class of 200 up to 500 species (Barthlott et al., 2007; Squeo et al., 1998).

This paper focuses on the driving factors for the two contrasting "hot" and "cold" spots of Andean plant diversity using at first a scale-dependant top-down approach. This includes global, zonal, and supra-regional aspects of evolutionary and paleo-ecological impacts on differing diversity patterns. Thereafter, special attention is given to the impact of natural disturbances on vascular plant richness, since some unique combinations of perturbative and stress features can be demonstrated. This will be illustrated by two examples, the "hotspot" situated in southern Ecuador in the Cordillera Real between Loja and Zamora, while the "cold spot" in northern Chile is located right near the Bolivian border northeast of San Pedro de Atacama. The south Ecuadorian example with an area of appr. $250 \mathrm{~km}^{2}$ comprises the entire Rio San Francisco Valley with a vertical span from 1660 up to $3140 \mathrm{~m}$ a.s.l. From a climatic point of view, the higher parts of this area rank among the "wettest spots" of the tropical Andes (s.b.) The north Chilean study area covers almost $725 \mathrm{~km}^{2}$ ranging from 2560 to $5970 \mathrm{~m}$ a.s.l. on the western slopes of the volcanoes Sairecabur and Licancabur (Fig. 1) and is located at the northern rim of the "driest spot" of the Andes (s.b.).

\section{General aspects of Andean biodiversity and perturbative impacts}

\subsection{Driving factors for patterns of Andean biodiversity}

By far most of the complex plant diversity pattern in the tropics and thus also in tropical high mountains has been developed from (mostly expanded) evolutionary processes and species history traits, while ongoing recent triggers of diversification can be largely reduced to local disturbance and regional stress effects. Stress such as high radiation rates might foster speciation by mutagen ramifications while the majority of disturbances like man-made clearings or natural landslides cause a temporary input of e.g. light- and/or drought-tolerant species and, if at all, at the utmost epigenetic responses in few taxa. In this chapter, the higher-ranking evolutionary preconditions for the high biodiversity in the northern and central Andes are introduced, while following chapters deal mainly with recent perturbative impacts on plant diversity.

A combination of multiple scale-dependent factors contributes to the above-mentioned strongly diverging degrees of phytodiversity (Grüninger, 2005; Levin, 1992; Richter et al., 2009). According to Grüninger and Fickert (2003, p. 199), "factors with a certain spatial or temporal extension create different-sized habitat types with different diversity patterns. Mechanisms that affect the diversity on one scale might not be effective on another, and a functional interpretation always has to be orientated on the different spheres of influence".

On a global scale the virtually ubiquitous species-rich tropical type of biodiversity in the humid Andes benefits from general (paleo-) ecological factors (Fig. 2a). Among the diversity triggers under wet tropical conditions, the effective evolutionary time since the mid-Tertiary plays a considerable role. It comprises a greater evolutionary speed at 


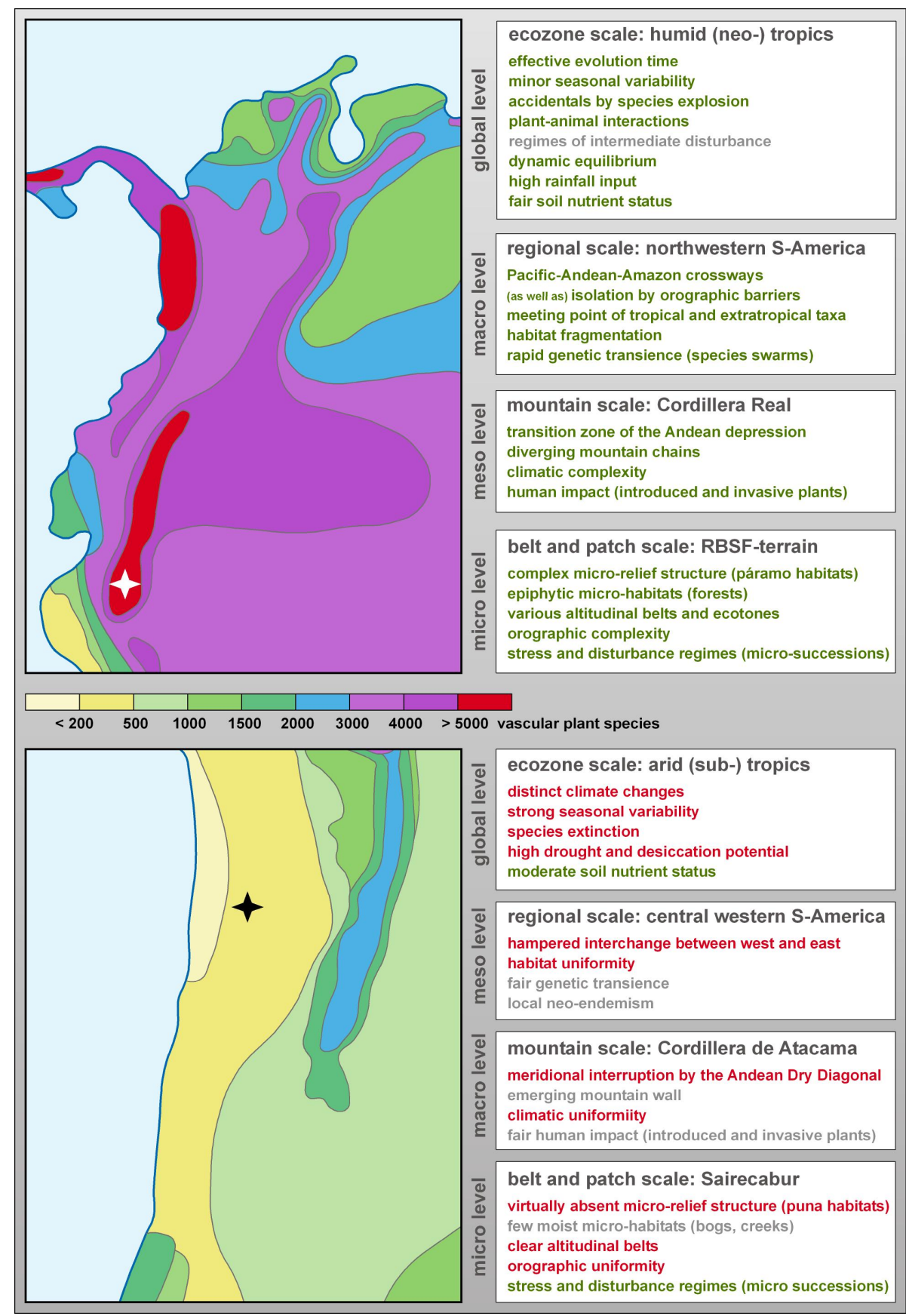

Fig. 2. Scale dependent factors contributing to plant diversity within the study area in southern Ecuador (above) and in the Cordillera de Atacama (below). Factors of predominantly positive effect on species richness are printed in green, while negative and minor consequences are in red and grey, respectively. Important controls of biodiversity within the four levels from global to microscale are expressed by boxes. The plant diversity maps on the left are based on a recent world map by Barthlott et al. (2007).

relatively constant tropical temperatures as well as a longer evolutionary time (Rohde, 1992) and leads to an elevated radiative speciation (Beck and Richter, 2008). Additionally, many "accidentals" exist, i.e. species that are poorly suited for different habitats and show low environmental tolerances, which inflate species numbers (Stevens, 1989).
Prance (1982) states that many plant-animal interactions are related to long-term dynamics of deeply coevolved relationships between taxa driven by natural selection in order to survive. Furthermore, low-latitude species are less capable to tolerate seasonal temperature fluctuations than high-latitude species, which sustain a harsher competitive evolutionary 
pressure (Stevens, 1996). Among present driving factors, high and largely non-seasonal annual rainfalls are considered a driving force behind high epiphyte diversity and abundant terrestrial fern species (Gentry and Dodson, 1987; Kessler, 2001). Finally, infertile soils seem to increase plant diversity in the tropics, since superior competitors are unable to dominate quickly and many species can coexist in a nonequilibrium state (Huston, 1994).

By comparison, one of the oldest deserts (Clarke, 2006) and probably driest place of the planet, the Atacama suffers from various negative influences on species richness (Fig. 2b). As in most other deserts of the tropical-subtropical transition zone, climate changes were (and are) highly effective. In the High Atacama, phases of extreme aridity alternating with cold-moist conditions (Geyh et al., 1999) inevitably led to phases of species extinction. Temperature and moisture variations between winter and summer are significant (Emck et al., 2007), causing a phenological synchronization that reduces the opportunities for regeneration (Runkle, 1989). Unlike the poor nutrient supply of many tropical rainforest ecosystems, desert environments tend to have greater mineral fertility. In the High Atacama, especially the mosaic of various volcanic substrates might have stimulated the evolutionary differentiation of taxa, i.e. in arid environments this factor is considered positive for desert soil variation and thus, plant diversity.

The macroscale focuses on northwestern South America, including the Andes with their foothills on the one hand and the dry transition between the Central and the southern Andes on the other hand. The northern Andes form an important interface between the so-called "Tumbes-ChocóMagdalena biodiversity hotspot" along the Pacific Coast and the Cordillera Occidental in the west and the Amazon lowlands with equivalent moist forests of the Napo-CasquetaMagdalena area in the east. In a meridional sense, both the western and the eastern region range from the Central American floristic zone in the north to the "Andean Depression" (syn. "Depression of Huancabamba"), which stretches southward from $3^{\circ} \mathrm{S}$ to $7^{\circ} \mathrm{S}$ as an essential division corridor towards the central Andes (Richter et al., 2009). Contrarily, the area around the "Andean Dry Diagonal Axis" crossing the Andes between $24^{\circ} \mathrm{S}$ and $26^{\circ} \mathrm{S}$ from SSE towards NNW stands for a zone of hampered floristic exchanges or even of species attrition.

The rugged terrain of the northern region creates a high variability of site conditions on short distances between wet gorges containing high rainforests and edaphically less humid ridges settled by low forest stands (Oesker et al., 2008). This spatial heterogeneity favours the development of endemic species swarms in the northern Andes. Among them Bromeliads and Orchids are strong agents of "evolutionary explosions" (Gentry, 1982). In contrast, the unbroken and generally smooth escarpments of the High Atacama are less suitable for habitat differentiation of highly specialised plant communities. Here, neo-endemism is therefore restricted to fewer genera, many of them being shrubs with protracted alternation of generations. They populate rather narrow sections at higher elevations or even isolated massifs (e.g. locally dispersed species of Asteraceae and Fabaceae; q.v. Moreira-Muñoz, 2007). Thus, compared to the rapid genetic transience of the humid tropical example, the arid Atacama represents moderate speciation rates in restricted areas.

The mesoscale level covers the Cordillera Real and its surroundings in southern Ecuador for the humid tropical and the northeastern arc around the Salar de Atacama for the dry Andes. North of the Andean Depression, the former benefits from taxonomic contributions from central Andean floristic provinces such as the Marañon dry forest, the Ucayali moist forest or the Peruvian Yungas. In the High Atacama, there is no such transition effect since the nearest floristic provinces are distant and, according to data of Morrison et al. (2001), similarly species-poor. In southern Ecuador, plant diversity also benefits from the orographic complexity given by several mountain chains, which diverge south- and southwestwards from a mountain junction called Nudo de Loja $\left(4^{\circ} \mathrm{S} / 79^{\circ} \mathrm{W}\right)$. The resulting inter-Andean ranges and valleys offer a high variety of wet and dry climates in close proximity to each other due to an extremely partitioned terrain with differently exposed slopes. The strongly contrasting amounts of rainfall may range between 350 and up to $8000 \mathrm{~mm} / \mathrm{a}$ across a distance of only $30 \mathrm{~km}$. Such differences foster elevated levels of endemism and numerous plant communities (Richter, 2003). By contrast, the gentle rise towards the emerging massif of the Cordillera de la Atacama leads to an unspectacular climate gradient with precipitation rates from $25 \mathrm{~mm} / \mathrm{a}$ in the basin up to $250 \mathrm{~mm} / \mathrm{a}$ at around $4500 \mathrm{~m}$ a.s.l. (Richter and Schmidt, 2002). Concerning the altitudinal gradient of plant diversity, both Andean regions, the moist as well as the dry one, are characterised by a so-called Mid-Domain-Effect (Colwell et al., 2004), i.e. non-linear vertical distributions of taxa with a culmination of species at mid-elevations. This effect leads to a chaotic HrandomH species distributionH in tropical mountain rainforests, where the discrete altitudinal vegetation belts typical for extratropical mountains are replaced by a continuous ecotone with its typical effect on species enrichment (Bach et al., 2007; Richter, 2008). Contrasting to this uninterrupted flux of taxa, the High Atacama shows a clear vertical belt structure (Richter, 2003) with limited cumulative effects within the short transitional passages from one belt to another.

On a microscale, research on plant diversity concentrates on local parameters such as structural patterns within plant communities. In the northern Andes, micro-habitats and their diversity structures play an important role with regard to epiphyte-rich forest environments due to an often extremely high niche complexity. Above timberline, i.e. at páramosites, different micro-habitats coexist as a consequence of the highly variable micro-relief and the heterogeneous effects of strong wind and precipitation. Even the smallest depressions and adjacent small rises contribute to a patchy 
mosaic of communities with surprisingly high species numbers (Richter et al., 2008). Both epiphytism and micro-relief variability do not apply to the High Atacama due to the absence of trees as well as a completely hyper-arid microclimate.

However, natural (micro-) successions are also part of the microscale level. Such dynamic processes result from stressing and perturbative effects. They are of both recent as well as local impact for diversity structures. Thus, the following examines accordant aspects in detail.

\subsection{Natural disturbances as triggers for Andean plant diversity}

Some of the above mentioned ecological triggers for tropical species-richness are related to each other, while two more seem to contradict another. The Intermediate Disturbance Hypothesis argues that biodiversity is highest at an intermediate rate of natural disturbances (Grime, 1973; Connell, 1978), which limits strong competitors and balances less competitive species best. While this hypothesis is developed as a theory of worldwide validity, in the context of tropical ecosystems Huston (1994) favours a broadened concept, i.e. the Dynamic Equilibrium Model. It assumes a dynamic equilibrium engendered by varying growth rates of individual species, by the intensity of interspecific competition, and by the frequency and intensity of disturbances. The latter framework fits with lowland rainforest ecosystems, in which apart from hurricane-prone areas autogenesis can be considered the main regeneration type (Whitmore, 1990), while perturbative effects are of lesser importance for regeneration processes. On the other hand, the Intermediate Disturbance Hypothesis and herewith combined mosaic cycles (Remmert, 1991) can explain distinct diversity patterns in mountain rain- and cloud forest ecosystems in rugged terrain. Here, some disturbance regimes constitute crucial triggers for an additional species input generated by consecutive succession stages between pioneer and mature communities in these ecosystems.

In general, natural disturbances are a prominent feature of high mountain regions, as rapid mass movements are widespread and other perturbative events such as storms or fires create gaps in the vegetation. However, some mountain areas are characterised by more disruptive events than others. In the wet Andes of southern Ecuador, flood and mudflow effects are more significant at lower reaches, while landslides and wildlife damage affect medium and higher elevations. In contrast, apart from local volcanic eruptions, disturbances in the Atacama are less frequent and violent. On the other hand, plant diversity is not alone influenced by the frequency and size of the events but the resilience of the vegetation might be even nmore important. In the Cordillera Real, droughts, for example, are less striking in the evergreen rainforests than at and above timberline. Here, plants suffer from stronger and faster soil desiccation and die off after few weeks without rain as observed after extended "Veranillo de Niño" events in late 2000 and 2005 (Richter et al., 2009). Of course, the same duration and intensity of drought would not have any effect in the High Atacama, where first drought consequences on vegetation become obvious after years or even decades.

Disastrous impacts, like vast fires or rockslides, cause large natural clearings in an ecosystem with a high probability of a protracted regenerative turnover. As for medium sized incidents, gaps with fast-developing understorey species waiting for their chance and lateral ingrowths by neighbouring trees competing for open spaces may cover the ground and fill up crown-breaks within a few months. The smallest dimension of disturbances refers to spot dynamics in herb and grass communities. Many of their plant species participate in a "merry-go-round" migration, causing a high probability of recolonisation by any of the species for each micro-site, while others are specialized on patchy openings caused by burrowers or cryoturbation. Small disturbances may produce comparatively short-term and straightforward micro-successions of few pioneer-generations, while huge devastations tend to implicate a long-lasting regeneration of the original ecosystem (Fig. 3).

\subsubsection{Perturbative effects on plant diversity in the humid tropical Andes of southern Ecuador}

Since one of the most striking features of the mountainscape in southern Ecuador is its wide climatic range meteo-driven incidents such as droughts, floods, landslides or mudflows cause obvious changes on the vegetation structure. Of those four factors, the first affects a large scale but has selective effects, while the other three vary from rare macro- to frequent meso-disturbances and may completely devastate vegetation. They are distributed over the whole area so that regions of twelve arid months are affected as well as those of no arid month. However, differences in frequency and intensity result in different impacts and responses depending on the resilience of the related ecosystem (and landform). For example, a flood in the dry area west of the Cordillera Real often creates more extended overflows and erosive consequences than a similar flood in the humid eastern side where river systems are to some extent adapted to this phenomenon. In contrast, droughts occur less frequently and intensely in Andean mountain rainforest areas but reduce plant vitality more rapidly compared to droughts in the inter-Andean drier valleys. The effect on species enrichment of both droughts and floods seems to be rather negative than positive, since even for genetically flexible species the net effect is negative.

This chapter focuses on three typical and rather specific disturbance types of the humid tropical Andes: (i) wildlife depredation in the páramo area above the timberline, (ii) cohort mortality in the upper mountain rainforest, and (iii) translational landslides. These regimes do not only differ in scale but also in their importance on diversification processes by multiple succession phases. 


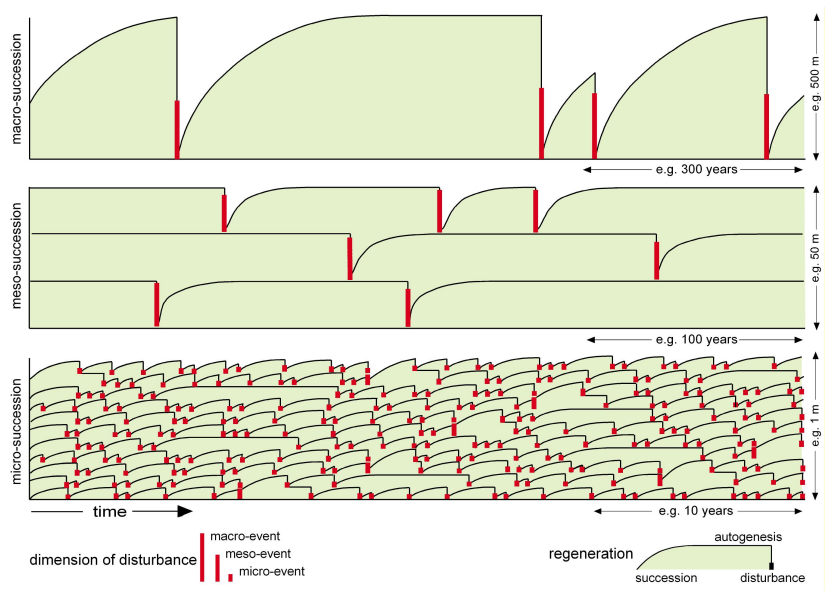

Fig. 3. Spatiotemporal dimensions of disturbances.

The first disturbance type is of minuscule to medium extent and ranges from the destruction of one individual plant to devastations of hectare-sized fields. It is mainly caused by the most prominent and destructive mammal inhabiting the temperate and cool zones of the Cordillera Real, the Andean or Spectacled Bear (Tremarctos ornatus). Apart from small vertebrates (rodents, birds, lizards) and insects (termites, ants, bees), its favoured food are fruits, seeds, fresh twigs and bamboo shoots, some epiphytic and especially terrestrial bromeliads. Forming large patches in the páramos of the crest areas, those fields sometimes convey an impression of heavily damaged "bear restaurants". However, these uniform Bromeliad stands seem to be very stable, since the remaining trunk corpus beneath the destroyed leaf rosettes are able to resprout shortly after. In this case an additional species input by pioneer species is very limited. Since harvesting is otherwise highly selective, damages by the Andean Bear as well as by the similarly acting Mountain Tapir (Tapirus pinchaque) are restricted to small patches in the páramo and elfin forest ecosystems. Nevertheless, they play an important role in endozoochorous dispersal as proven by feces packed with seeds.

A striking example of destructive mass movement processes that foster plant diversity is soil or debris creep. Richter et al. (2009) document a five year survey on a site in the Cordillera Real situated on a mobile debris layer at around $3080 \mathrm{~m}$ a.s.l. By far most of the solitary tree stems are inclined due to a downward shift of the debris. Before 2003 , the site was settled by a monotypical bamboo cohort of Chusquea scandens that flowers only once at the end of its lifetime and then dies off (Fig. 4b). Since 2003, the vivid recolonisation through pioneers presents a completely different aspect consisting of a heterogeneous structure due to a transient community of highly diverse species (Fig. 4c-f). So far, further types of cohort mortality like those induced by insect plagues are not noticeable in the research area due
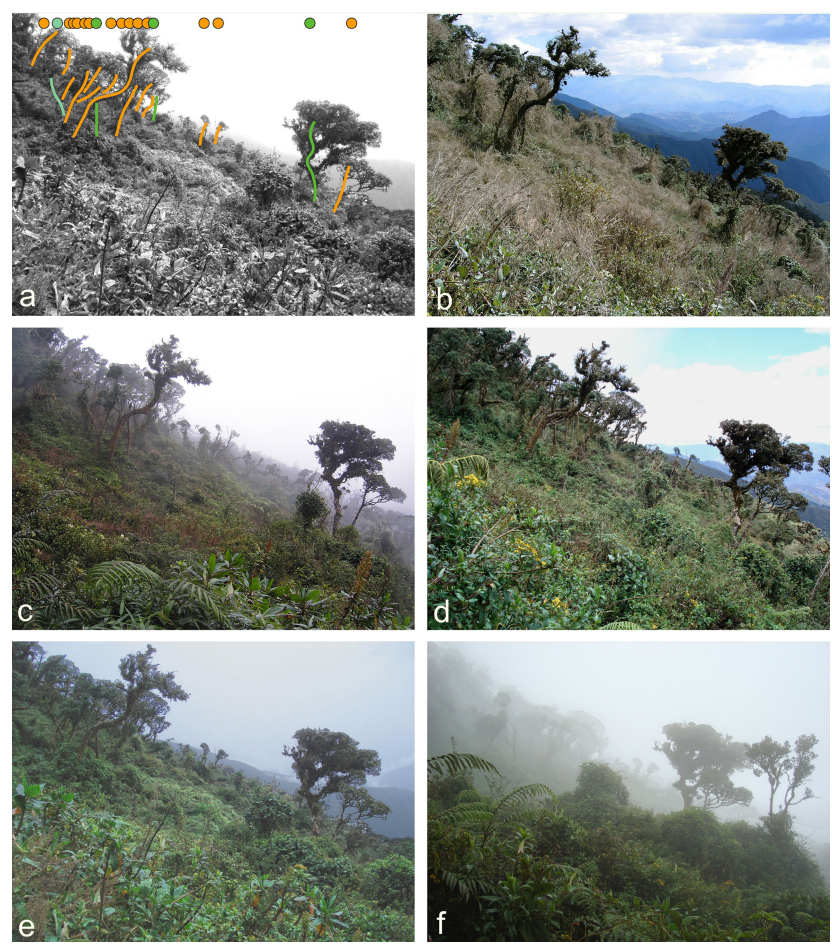

Fig. 4. Cohort mortality of Chusquea scandens (b) and subsequent plant sucession of herbaceous and shrubby pioneers (c-f) at about $3080 \mathrm{~m}$ a.s.1. in Cajanuma. 14 inclined trees marked orange indicate the effect of debris creep, while 4 (green) are apparently unaffected by the slow mass movement process (a). (b-f) taken in Octobre 2004-2008.

to the mostly polyspecific structure of natural forests. However, leaf damage on Alnus acuminata, which tends to build up monospecific stands, indicates heavy pest infestation in several mountain rainforest areas of the moist tropical Andes.

One of the most prominent disturbance regimes of the research area is landslide activity (Brenning, 2005). It occurs in many earthquake prone terrains of the eastern tropical Andes marked by steep orography, inclined schist layers, and humid climate. Here, most mass movement processes are classified as shallow transitional landslides and debris flows. Triggered by steady rainfall and sometimes by earthquakes, landslides in the mountain rainforests on the windward escarpment of the Cordillera result mostly from the destabilisation of thick, water-soaked humus layers and the weight of the forests rooting in it. The spatiotemporal pattern of unevenly aged landslides governs a mosaic cycle of the slope forest ecosystem and enables a rather fast plant recovery. The chronology of sliding is subject to biotic and hydrologic controls characterised by an oscillation between slope stability and instability (Fig. 5b). The destabilisation is induced by growing forests, while after the slip, the altered flow regime and regenerating root systems foster fast stabilisation. 
At landslide sites, the first pioneers are cryptogams including algae and fungi. According to Lozano et al. (2008), mosses and lichens build up a complete coverage. It allows the establishment of ferns (Gleicheniaceae, Dryopteridaceae, and in higher reaches Blechnaceae), herbs (species-rich genera of Orchidaceae), Asteraceae and grasses (Poaceae, especially Cortaderia and Chusquea) during the first years. Shortly thereafter, several dwarf shrubs become prominent members, among them many Ericaceae and once again Asteraceae. Secondary shrub succession starts with the appearance of Melastomataceae and Piperaceae before Rubiaceae, Lauraceae and Myrtaceae as abundant tree taxa gain importance. Although sliding processes seem to depend on forest weight and hence on forest age, no fixed recurrence interval of such events can be given since additional interactive parameters vary considerably.

Moderate disturbance impacts result from natural fires and tree breakages causing small gaps. In present time, it is difficult to differentiate between wildfires and man-made fires, which are by far preponderant. On the other hand, Behling (2008) reports on fire impacts during the Holocene, which must be considered natural events. The grass- and shrublands above timberline are the ecological zone most prone to such incidents. Here, terrestrial Bromeliad patches once again benefit as highly fire resistant plant formations. Increased ignitability is mostly linked to longer dry periods in more arid regions of the inter-Andean Sierras or to droughts during El Niño periods in the Andean parts, respectively.

\subsubsection{Perturbative effects in the Andean Arid Diagonal}

Interestingly, in contrast to the wet mountains in the tropical Andes, wildlife plays a major role in plant species enrichment in the arid Cordillera de Atacama. Among them guana$\cos$ (Lama guanicoe) in its northern and vicuñas (Vicugna vicugna) in the central section prevail among the South American camelids. Living in the puna grasslands at an altitude of 3500 to $5000 \mathrm{~m}$, they feed especially on Festuca grasses and Oxychloe of the rush family, the latter building up the Andean bogs, the "bofedales". Their perturbative impact is concentrated on patchy "Lama toilets" causing high nitrogen inputs and thus also a specific nitrophilous plant community of annual herbs (Fig. 6).

In comparison to Lamoids, small subterranean rodents of the mouse species Ctenomys opimus, commonly known as tuco-tucos, impact much vaster terrains by their burrow activity (Fig. 7). Their dens consist of a dense net of tunnels with diameters of $5-7 \mathrm{~cm}$ around $30 \mathrm{~cm}$ below the surface and comprise sleeping chambers lined with straw, compartments for food storage, as well as restrooms. Roots, tubers, stalks, and grasses are their preferred nutrition, the latter mostly being pulled down into the den. The tuco-tucos populate huge terrains of preferably sandy ground, which is highly unstable when walking on it. The underground system
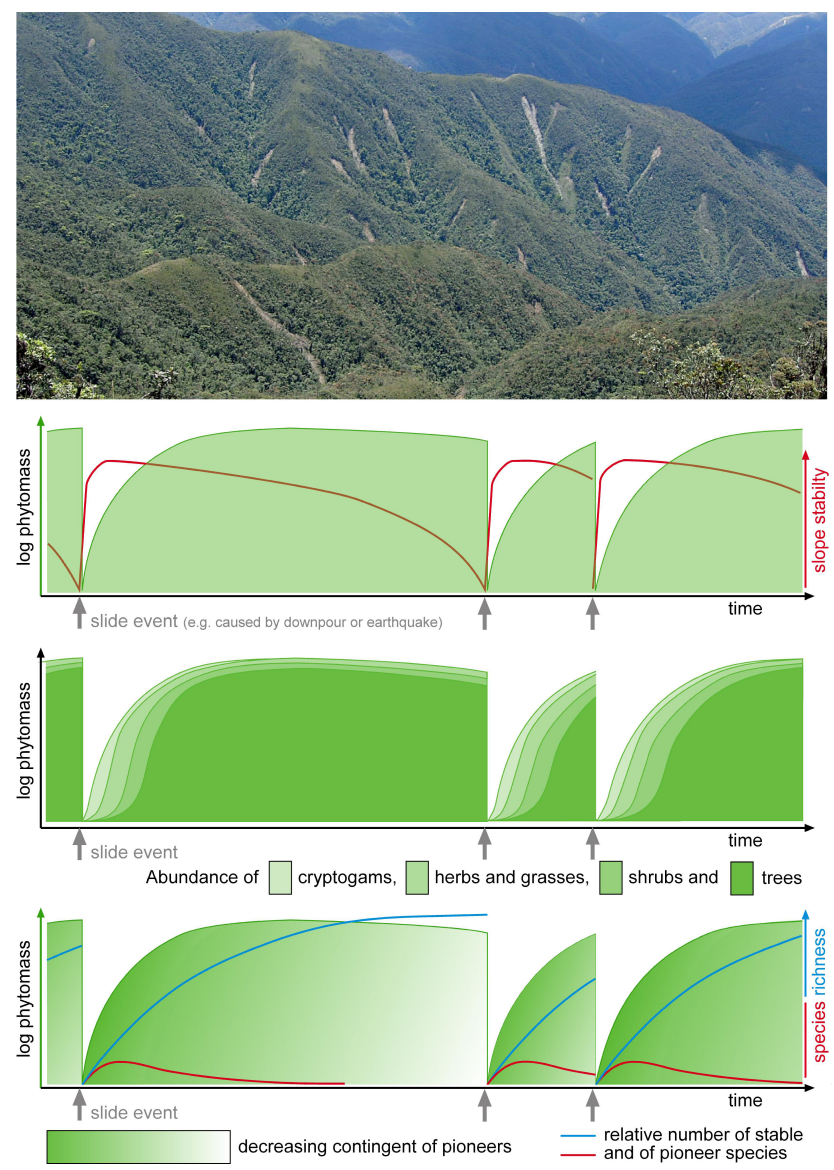

Fig. 5. Landsliding as trigger for regenerative mosaic cycles of mountain rainforests. Active sliding zone between 2300 and $2600 \mathrm{~m}$ a.s.l. on the terrain of the Reserva Biológica San Francisco in southern Ecuador (a); (b) depicts the relationship between phytomass (green field) and slope stability (red line); biomass weight causes overloading and leads to slope instability. Arrows indicate the occurrence of landslide events; (c) illustrates non-linear trajectories describing changes in the abundance of different functional groups of plants through time (area under each curve); (d) highlights the additional input of vascular plant pioneers recolonising the landslides. The time scale is on the order of few centuries.

with its deposits for feed and faeces, respectively, harbours a scattered seed bank. Especially after rainfalls during the warmer period of the "Invierno Boliviano", annual herbs of Lupinus and Phacelia, both genera of high genetic plasticity, are evenly dispersed between tussocks of perennial grasses. However, after a depletion of the seed banks, the restart of the mosaic cycle depends on a re-establishment of anemochorous invaders. Long stages of bare ground may be the consequence (Fig. 7).

Perturbative influences by gelifluction comprise microstructures such as creeping soil-lobes, sorted stripes or circles as well as macro-landforms such as vast frost-debris scree surfaces above $4300 \mathrm{~m}$ a.s.l. As frequent (almost diurnal) freeze-thaw-cycles at shallow ground depth are already 


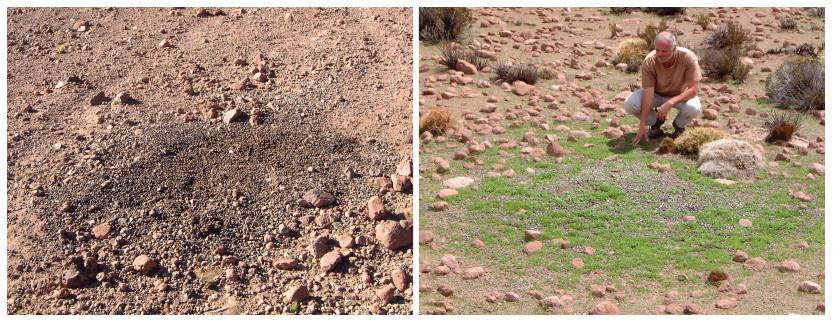

Fig. 6. Concentrated nitrogen input caused by excrements and urine of vicuña and guanaco. Note the narrow lawn of a special herb community adapted to the strong eutrophication on the right picture after several downpours at the base of Volcán Sairecabur at 3900 m a.s.l. Left: dry deposits at the base of Volcán Llullaillaco at $4500 \mathrm{~m}$ a.s.l. (photos: March 2001).

notable just above $4100 \mathrm{~m}$ a.s.l. (Richter and Schmidt, 2002), periglacial morphodynamics start to influence plant growth at this altitude. Further denudation processes result from rainfalls, which form narrow mudflows up to areas of extended sheet wash with subsequent encrustation and contraction of cracks at the surface of gypseous substrates. They are more frequent at lower altitudes between 2000 and $4000 \mathrm{~m}$ a.s.l., and occur especially in the Cordillera del Sal. Both denudative processes, the periglacial one as well as the slow-acting surface flow, act in a much less dramatic mode, much slower and much closer to the surface than (nonexistent) landslides would. Therefore they do not disturb plant growth or influence plant diversity considerably.

Positive effects of floods on plant diversity in the Atacama are hardly conceivable. In early 2001, strong discharges generated by heavy downpours caused localized but complete devastation in narrow valley sections along the Quebrada de la Zorrita downstream of the western escarpment of Volcán Llullaillaco. The same event affected vast stands of Cortaderia-tussocks along the Quebrada de Guatín southwest of Volcán Sairecabur, which, unlike the former site, regenerated quite well during the following years. However, no longterm change or replenishment of the flood-adapted plant association was found. The self-evident reason behind this stable community compound is the limited amount of upstream riverine taxa, which are likewise less viable under warmer climate conditions.

Small wetlands at lower elevations harbour quite often monotypic Tessaria absinthoides shrubs which are frequently infected by an insect-pest. While many affected individuals suffer from violent infestation and die off, these damages do not evidence any change in plant diversity.

\subsection{Stress effects on Andean plant diversity}

In general, climatic extremes like droughts, gales, or superabundant precipitation and radiation inputs have widespread impacts with partially long-lasting effects. Nevertheless, these phenomena have to be attributed to microscale factors

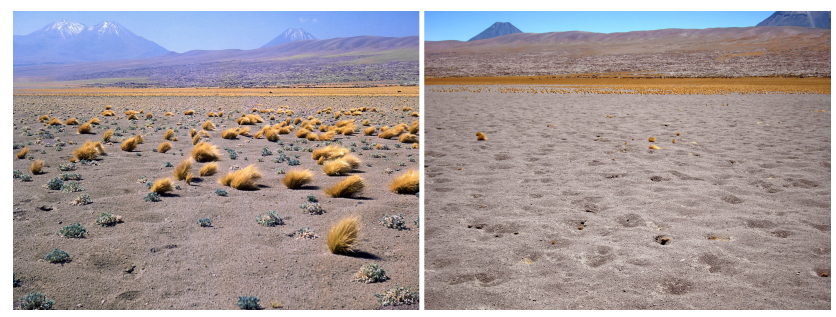

Fig. 7. Puna of Festuca grassland near Laguna Miscanti at $4100 \mathrm{~m}$ a.s.1. While the left picture shows vivid sprouts of annual herbs and perennial grasses after the moist season in late March 1994 the right picture of the same area indicates a desolate aspect of an "overgrazed" wasteland after the tuco-tucos withdrew from the area (December 2008).

since they affect only plant individuals but not entire communities. The same is valid for ecological stress, which is a near relative of natural disturbance and may also influence plant diversity. In most cases, the above-mentioned droughts are rather stressing than perturbative influences on plants, which are better adapted to it in the Cordillera de Atacama than in the Cordillera Real. This underlines the decisive difference between disturbance and stress: if a stressing factor such as drought leads to plant death, the event must be assigned to the complex of disturbances. This is also true for the strong wind regimes in both mountain ranges, i.e. boisterous westerlies during afternoons in the Atacama and quasi-permanent easterlies in the Cordillera Real. However, since destructive storms are not observed in either region, the existing taxa are mechanically and physiologically adapted to high wind speeds without showing any mutagen response.

While droughts and wind have no positive effects on plant enrichment, superabundant rainfall indirectly does. In case of the Cordillera Real, the nutrient-poor soils of the area are not only caused by the mineral poverty of the underlying lithosphere but also by precipitation amounts of 4000 to more than $6000 \mathrm{~mm} / \mathrm{a}$ at higher elevations. Consequently, water logging is prevalent on flat ridges due to reduced interflow run-off, where it impairs tree growth from as low as $2600 \mathrm{~m}$ a.s.l. upwards, and favours grass- and shrubland. In spite of the perhumid conditions, endemism is extremely high in the wet páramos of the Cordillera Real (Quizhpe et al., 2002) with Gynoxis, Neurolepis, and Tillandsia being some prominent taxa. Hence, the above noted "rainfalldiversity hypothesis" along with a "low soil nutrient hypothesis" serve as a good explanation for a cold tropical environment, too.

With regard to the extremely high precipitation amounts in the Cordillera Real, it appears surprising that the same localities on top of the mountain range are exposed to extraordinarily high values of global irradiance, too (up to $1832 \mathrm{~W} / \mathrm{m}^{2}$, Emck and Richter, 2008). Since cloud-radiative effects have been singled out as the exclusive source of this "super-irradiance", UV radiation with its mutagen potential 
must be considered to reach record high levels as well. In the Cordillera Real, some plant families stand out by vivid reddish or purple colors of their young tissues which trace back to high contents of HanthocyaninHs or carotenoids protecting cells from photoinhibition. Among them, Blechnaceae, Clusiaceae, and especially Ericaceae as well as Huperziaceae are species-rich members with probably high speciation rates at higher reaches of the region. While the highly variable radiation in the Cordillera Real is influenced by short-term extreme irradiance inputs, diurnal clear-sky radiation in the Atacama also fosters speciation of genetically malleable taxa. For example, herbaceous Composites such as Chaetanthera, Perezia, and Senecio are among the genera that enrich plant diversity.

Salt stress at riverine sites causes morphological phenotypes of several taxa, however this environmental factor seems to cause rather epigenetic than mutagen effects and thus may contribute to a high genetic but not species diversity.

\section{Conclusions}

Unlike the relatively dry Andean areas, species richness in the Cordillera Real benefits from almost all of the aforementioned ecological factors affecting plant diversity (Fig. 2). Only a few of them have no or little effect, whether due to low intensity or low frequency (Fig. 8). For example, human impact is still moderate within the San Francisco Valley itself, where it even contributes to species enrichment (although by introducing invaders). On the mesoscale, however, human influence already causes a loss of species, especially within the more intensively deforested, relatively densely populated areas of the inter-Andean Sierras. On the macroscale, both the species extinction rate and the input of less desirable invaders exceed the speciation rate. The exuberant land use in the lowlands of northwestern South America is the main reason for this. As the capitalisation of tropical rainforests is mostly based on deforestation, many positive macroscale or global scale factors such as a rapid genetic transience, species explosion by accidentals, vivid plant-animal interactions, or intermediate disturbance impacts no longer apply there.

The introduction of alien plants from extra-tropical lowlands affects the high altitudes of the wet tropics more than those of the arid tropical/subtropical Cordillera de Atacama. Here, inputs by casual as well as intentional introduction of non-native species are largely restricted to irrigated land-use systems, while human impact on species diversity has no consequences outside the oases. In contrast to the wet tropical Andes almost all of the global-scale down to microscale disturbances have little effect on plant diversity or even involve taxonomic depletion rather than enrichment. The only positive agents are some animal-driven impacts (tuco-tucos, Lamoids) and mutagen effects due to high radiation rates (Fig. 8).

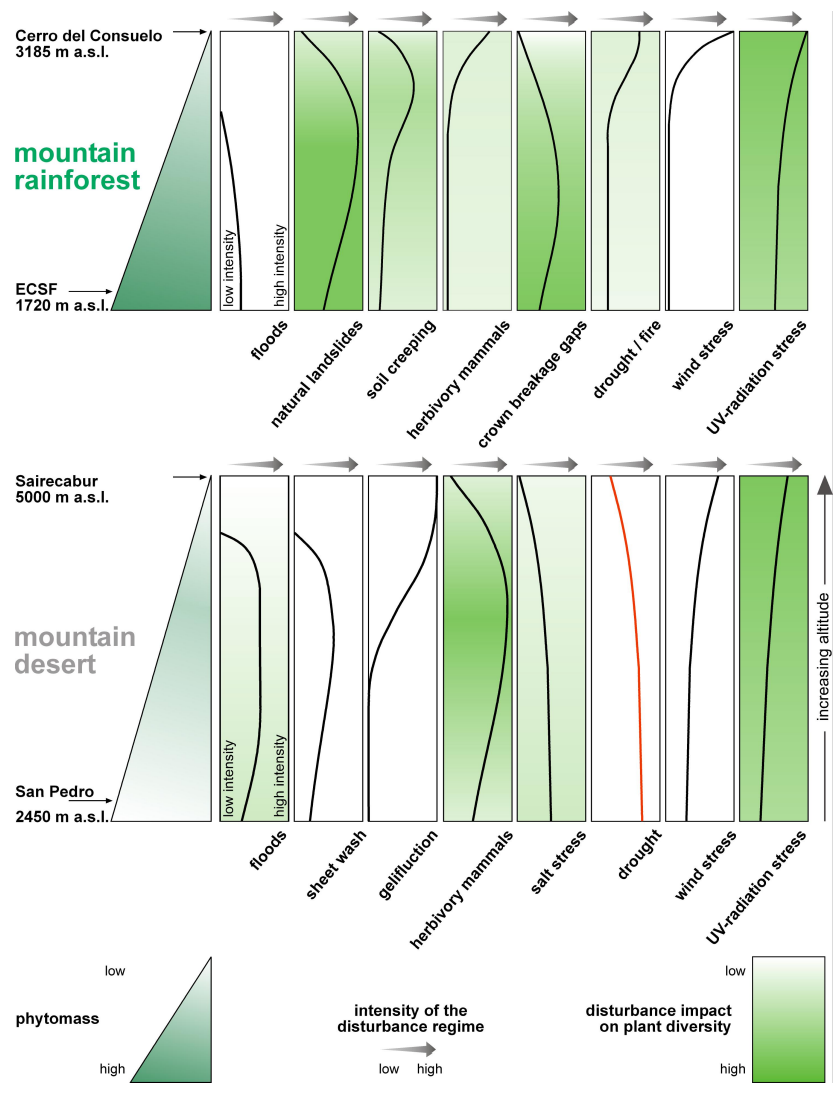

Fig. 8. Relative intensity (i.e. frequency and extensiveness, see arrow in the legend) of natural disturbances or stress (lines) and importance of perturbative effects for vascular plant diversity (colours) within the two study areas representing the perhumid part (top, i.e. the San Francisco Valley above the Scientific Station ECSF) and the arid Andes (below, i.e. the western escarpment of the high Atacama below Volcán Sairecabur).

Although the high species richness of the first example results from many positive triggers, while the second case benefits only from few driving forces, the relative importance of natural disturbance and stress regimes is similarly positive for both areas. This is even more surprising as most natural disturbances regimes in the wet tropical Andes induce multiple subsequent succession stages, which last for years or decades, while only a few rare and smaller disturbances in the dry Cordillera initiate mainly short and basic micro-successions. According to a rough estimation based on surveys in smaller areas, the San Francisco catchment in Fig. 1 hosts around 2000 native vascular plant species, while the three times larger area west of Volcán Sairecabur has appr. 250 species (with a high portion of species along creeks and in wetlands). These values correspond well with data given by Homeier and Werner (2008) and Squeo et al. (1998). Independent of the differences in the numbers of species studied, in both cases the author supposes that approximately $10 \%$ of the total inventory are pioneers of 
successive stages after natural disturbances, or recent products of mutagen stress effects.

Research on the relation between disturbance ecology and vegetation dynamics started some 20 years ago and led to an extensive knowledge on extratropical and subtropical disturbance regimes of widespread ecosystems, including some of the adjacent mountains (e.g. Böhmer and Richter, 1997; White and Jentsch, 2001). To date, similar research in the Andes is limited and virtually confined to the southern parts (e.g. Rebertus et al., 1993; Raffaele et al., 2007). The paper tries to encourage further investigation on these highly attractive inter-disciplinary ecological questions, which gain further importance with future human and climate-change impacts on ecological processes and their effects on the maintenance of tropical Andean biodiversity.

Acknowledgements. The author gratefully thanks the German Research Foundation (DFG) for funding the Ecuador project within the research group FOR 402 and FOR 816 as well as the earlier Atacama project RI 370/2. Thanks also to Peter Fabian for his generous support during the conference, to Alexander Brenning and to Iris Burchardt for proofreading as well as to two reviewers for their valuable comments.

Edited by: P. Fabian

Reviewed by: two anonymous referees

\section{References}

Bach, K., Kessler, M., and Gradstein, S. R.: A simulation approach to determine statistical significance of species turnover peaks in a species-rich tropical cloud forest, Divers. Distrib., 13, 863-870, 2007.

Barthlott, W., Hostert, A., Kier, G., Küper, W., Kreft, H., Mutke, J., Rafiqpoor, D., and Sommer, J. H.: Geographic patterns of vascular plant diversity at continental to global scales, Erdkunde, 61, 305-315, 2007.

Beck, E. and Richter, M.: Ecological aspects of a biodiversity hotspot in the Andes of southern Ecuador, in: The Tropical Mountain forest - Patterns and Processes in a Biodiversity Hotspot, edited by: Gradstein, S. R., Homeier, J., and Gansert, D., Biodiv. Ecol. Ser., 2, 197-219, 2008.

Behling, H.: Tropical mountain forest dynamics in Mata Atlantica and northern Andean biodiversity hotspots during the late Quaternary, in: The Tropical Mountain forest - Patterns and Processes in a Biodiversity Hotspot, edited by: Gradstein, S. R., Homeier, J., and Gansert, D., Biodiv. Ecol. Ser., 2, 25-33, 2008.

Böhmer, J. and Richter, M.: Regeneration of plant communities an attempt to establish a typology and a zonal system, Plant Res. Developm., 45, 74-88, 1997.

Brenning, A.: Spatial prediction models for landslide hazards: review, comparison and evaluation, Nat. Hazards Earth Syst. Sci., 5, 853-862, 2005,

http://www.nat-hazards-earth-syst-sci.net/5/853/2005/.

Clarke, J. D. A.: Antiquity and aridity in the Chilean Atacama Desert, Geomorphology 73, 101-114, 2006.
Clinebell, R. R., Phillips, O. L., Gentry, A. H., Stark, N., and Zuuring, H.: Prediction of neotropical tree and liana species richness from soil and climatic data, Biodivers. Conserv., 4, 56-90, 1995.

Colwell R. K., Rahbek, C., and Gotelli, N. J.: The mid-domain effect and species richness patterns: what have we learned so far?, Am. Nat., 163, E1-E23, 2004.

Connell, J. H.: Diversity in tropical rainforests and coral reefs, Science, 199, 1302-1310, 1978.

Emck, P., Muñoz Moreira, A., and Richter, M.: El clima y sus efectos en la vegetación, in: Botánica Económica de los Andes Centrales, edited by: Moraes, M., Øllgaard, B., Kvist, L. P., Borchsenius, F., and Balslev, H., La Paz, 11-36, 2007.

Emck, P. and Richter, M.: An upper threshold of enhanced global shortwave irradiance in the troposphere derived from field measurements in tropical mountains, J. Appl. Meteorol. Clim., 47, 2828-2945, 2008.

Gentry, A. H.: Patterns of neotropical plant species diversity, Evol. Biol., 15, 1-84, 1982.

Gentry, A. H. and Dodson, C. H.: Diversity and Biogeography of neotropical vascular Epiphytes, Ann. Mo. Bot. Gard., 74, 205233, 1987.

Geyh, M., Grosjean, M., Núñez, L. A., and Schotterer, U.: Radiocarbon Reservoir Effect and the Timing of the Late-Glacial/Early Holocene Humid Phase in the Atacama Desert (Northern Chile), Quaternary Res., 52, 143-153, 1999.

Grime, J. P.: Control of species density in herbaceous vegetation, J. Environ. Manage., 1, 151-167, 1973.

Grüninger, F.: Scale dependent aspects of plant diversity in semiarid high mountain regions, Passauer Schriften zur Geographie, 21, Passau, 2005.

Grüninger, F. and Fickert, Th.: Revealing diversity patterns of vascular plants and their causes in semiarid high mountain regions - a top down approach for Great Basin mountain ranges, USA, Erdkunde, 57(3), 199-215, 2003.

Homeier, J. and Werner, F.: Spermatophyta checklist - Reserva Biologica San Francisco, in: Provisional checklist of flora and fauna of the San Francisco Valley and its surroundings, edited by: Liede-Schumann, S. and Breckle. S.-W., Ecotropical Monographs, 4, 15-58, 2008.

Huston, M. A.: Biological Diversity. The coexistence of species on changing landscapes, Cambridge University Press, Cambridge, 1994.

Kessler, M.: Pteridophyte species richness in Andean forests in Bolivia, Biodivers. Conserv., 10, 1473-1495, 2001.

Levin, S. A.: The problems of pattern and scale in ecology, Ecology, 73, 1943-1983, 1992.

Lozano, P., Bussmann, R., Küppers, M., and Lozano, P.: Deslizamientos naturales y comunidades pionera de ecosistemas monzanos al occidente del Parque Nacional Podocarpus (Ecuador), Caldesia, 30(1), 1-19, 2008.

Margalef, R.: Dynamic aspects of diversity, J. Veg. Sci., 5, 451456, 1994.

Mittermeier, R. A., Robles Gil, P., and Mittermeier, C. G. (Eds.): Megadiversity: Earth's Biologically Wealthiest Nations, Monterrey, Mexico, 1997.

Moreira-Muñoz, A.: Plant Geography of Chile. An Essay on Postmodern Biogeography, Erlangen, 207, online available at: http: //www.opus.ub.uni-erlangen.de/opus/volltexte/2007/632/, 2007.

Mutke, J. and Barthlott, W.: Patterns of vascular plant Diversity at 
continental to global scales, Biol. Skr., 55, 521-531, 2005.

Mutke, J. and Barthlott, W.: Biodiversität und ihre Veränderungen im Rahmen des Globalen Umweltwandels: Biologische Aspekte, in: Biodiversität, edited by: Lanzerath, D., Barthlott, W., Mutke, J., Spranger, T. M., Baumgärtner, S., and Becker, C., Alber Verlag, Freiburg, 2008.

Oesker, M., Dalitz, H., Gunter, S., Homeier, J., and Matezki, S.: Spatial heterogeneity patterns - a comparison between gorges and ridges in the upper part of an evergreen lower montane forest, in: Gradients in a Tropical Mountain Ecosystem of Ecuador, edited by: Beck, E., Bendix, J., Kottke, I., Makeschin, F., and Mosandl, R., Ecol. Stud., 198, 267-275, 2008.

Peyton, B.: Spectacled Bear Conservation Action Plan, in: Bears. IUCN/SSC, edited by: Serbheen Ch., Herrero St., and Peyton, B., Gland, Switzerland, 157-198, 1999.

Prance, G. T.: Forest Refuges: evidence from woody angiosperms, in: Biological diversification in the tropics, edited by: Prance, G. T., Columbia Univ. Press, New York, 137-157. 1982.

Quizhpe, W., Aguirre, Z. M., Cabrera, O., and Delgado, T. E: Los páramos del Parque Nacional Podocarpus, in: Parque Nacional Podocarpus, edited by: Aguirre, Z. M., Madsen, J. E., Cotton, E., and Balslev, H., Abya-Yala, Quito, 79-90, 2002.

Raffaele, E., Kitzberger, T., and Veblen T. T.: Interactive effects of introduced herbivores and post-flowering die-off of bamboos on tree regeneration and the understory in a Nothofagus forest, Argentina, J. Veg. Sci., 18, 371-376, 2007

Rebertus, A. J., Veblen, T. T., and Kitzberger, T.: Gap formation and dieback in Fuego-Patagonian Nothofagus forests, Phytocoenologia, 23, 582-599, 1993.

Remmert, H.: The mosaic-cycle concept of ecosystems - an overview, in: The mosaic-cycle concept of ecosystems, edited by: Remmert, H., Springer Verlag, Berlin, Heidelberg, New York, 1-21, 1991.

Richter, M.: Using plant functional types as climatic indicators in the Cordillera, Lyonia 4(1), 1-18, www.lyonia.org/Archives/, 2003.

Richter, M.: Tropical mountain forests - distribution and general features, in: The Tropical Mountain forest - Patterns and Processes in a Biodiversity Hotspot, edited by: Gradstein, S. R., Homeier, J., and Gansert, D., Biodiv. Ecol. Ser., 2, 7-24, 2008.
Richter, M. and Schmidt, D.: Cordillera de la Atacama - das trockenste Hochgebirge der Welt, Petermanns Geographische Mitteilungen, 146, 48-57, 2002.

Richter, M., Diertl, K.-H., Peters, T., and Bussmann, R.: Vegetation structures and ecological features of the upper timberline ecotone, in: Beck, E., Bendix , J., Kottke, I., Makeschin, F., and Mosandl, R., Gradients in a Tropical Mountain Ecosystem of Ecuador, Ecol. Stud., 198, 123-136, 2008.

Richter, M., Diertl, K.-H., Emck, P., Peters, T., and Beck, E.: Reasons for an outstanding plant diversity in the tropical Andes of Southern Ecuador, Landscape Online, 12, 1-35, doi:10.3097/LO.200912, online available at: http://www.landscapeonline.de/archive/2009/12/ Richter_etal_LO12_2009.pdf, 2009.

Runkle, J. R.: Synchrony of regeneration, gaps, and latitudinal differences in tree species diversity, Ecology, 70, 546-547, 1989.

Squeo, F. A., Cavieres, L. A., Arancio, G., Novoa, J. E., Matthei, O., Marticorena, C., Rodriguez, R., Arroyo, M. T. K., and Muñoz, M.: Biodiversidad de la flora vascular en la Región de Antofagasta, Chile, Revista Chilena de Historia Natural, 1, 571-591, 1998.

Stevens, G. C.: The latitudinal gradient in geographic range: how so many species coexist in the tropics, Am. Nat., 133, 240-256, 1989.

Stevens, G. C.: Extending Rapoport's rule to Pacific marine fishes, J. Biogeogr., 23, 149-154, 1996.

White, P. S. and Jentsch, A.: The search for Generality in Studies of Disturbance and Ecosystem Dynamics, Prog. Bot., 62, 399-449, 2001.

Whitmore, T. C.: An introduction to tropical rain forests, Clarendon Press, Oxford, 1990.

Willig, M. R. H., Kaufman, D. M. H., and Stevens, H. R. D.: Latitudinal gradients of biodiversity: pattern, process, scale and synthesis, Ann. Rev. Ecol. Syst., 34, 273-309, 2003. 